\begin{tabular}{|c|c|c|}
\hline 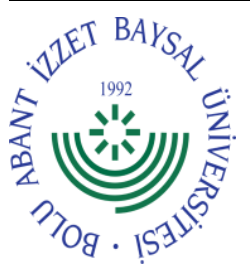 & $\begin{array}{l}\text { International Journal of Agriculture and Wildlife } \\
\qquad \text { Science } \\
\text { http://dergipark.org.tr/ijaws }\end{array}$ & 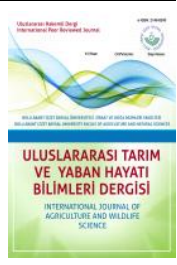 \\
\hline
\end{tabular}

Research Article

\title{
Morphological Diversity of Pyrus elaeagrifolia Pall. Ecotypes in Eastern Anatolia Region
}

\author{
Mehmet Ramazan Bozhüyük \\ Department of Plant and Animal Production, Vocational School of Technical Sciences, Igdir University, Igdir, Turkey
}

Received: 10.08.2021 Accepted: 01.10.2021

\section{Keywords: \\ Pyrus elaeagrifolia, drought resistant, morphological diversity, pomology}

\begin{abstract}
One of the wild fruit species that has been in demand in the markets in Turkey in recent years is oleaster-leafed pear (Pyrus elaeagrifolia). This species, which is widespread especially in arid areas in Turkey, is represented by a wide morphological diversity. It is found in general rural areas and its fruits collected and valued by rural people. In this study it was determined phenological (including ripening period) and some important morphological parameters of eight pre-selected promising oleaster-leafed pear (Pyrus elaeagrifolia) ecotypes. Ripening dates of ecotypes were observed between 25 October and 12 November. Fruit mass were in range of 8.36 to $16.11 \mathrm{~g}$ indicates a 2 -fold difference between the ecotype with the lowest fruit weight and the ecotype with the highest fruit weight. Shape index were changed from 0.87 to 1.07. Fruit pedicel length and fruit firmness were found between 9.13 to $16.32 \mathrm{~mm}$ and 4.47 to $7.89 \mathrm{~kg} \mathrm{~cm}^{-2}$, respectively. The ecotypes S1, S4 and S6 can be advanced for commercial cultivation; furthermore, other ecotypes can be used as source of breeding lines for genetic improvement of oleaster-leafed pear.
\end{abstract}

Corresponding author
mrbozhuyuk@gmail.com

\section{Doğu Anadolu Bölgesi Pyrus elaeagrifolia Pall. Ekotiplerinin Morfolojik Çeşitliliği}

Anahtar kelimeler:

Pyrus elaeagrifolia, kuraklığa dayanım, morfolojik çeşitlilik, pomoloji
Özet. Türkiye'de pazarlarda son yıllarda rağbet gören yabani meyve türlerinden birisi ahlattır (Pyrus elaeagrifolia). Türkiye'de özellikle kurak bölgelerde yaygın olarak bulunan bu tür, geniş bir morfolojik çeşitlilik ile temsil edilmektedir. Ahlat genel olarak kırsal alanlarda ve bu alanlarda yaşayan insanlar tarafından toplanan ve değer verilen meyvelerden birisidir. Bu çalışmada ön seleksiyonla belirlenen ümitvar 8 ahlat (Pyrus elaeagrifolia) ekotipinin fenolojik (hasat zamanı) ve bazı önemli morfolojik parametreleri incelenmiştir. Ekotiplerin olgunlaşma tarihleri 25 Ekim ile 12 Kasım arasında gözlemlenmiştir. Ekotiplerde meyve ağırlığı 8.36-16.11 g aralığında olup, meyve ağırlığı en düşük olan ekotip ile en yüksek meyve ağırığına sahip ekotip arasında meyve ağırlığı bakımından 2 kat fark olduğu ortaya çıkmıştır. Şekil indeksi 0.87 ile 1.07 arasında değişmiştir. Meyve sapı uzunluğu ve meyve sertliği sırasıyla 9.13-16.32 mm ve 4.47-7.89 $\mathrm{kg} \mathrm{cm}^{-2}$ arasında bulunmuştur. Çalışma sonunda S1, S4 ve S6 ekotipleri ticari yetiştiricilik için önemli bulunmuş ve diğer ekotiplerinde ıslah materyali olarak kullanılabileceği ortaya çıkmıştır. 


\section{INTRODUCTION}

Anatolia is accepted like open air museum of wild edible fruits because most of the temperate wild edible fruits has been propagated by seeds in this area and consumed fresh or mostly processed into several traditional product for centuries. In Turkey rural people are familiar with a wide range of different wild edible fruits. Wild edible fruits are also one of the important elements of natural landscape of Anatolia (Yildiz et al., 2010; Tetik et al., 2011; Sezen et al., 2015; Ercisli and Sagbas, 2017).

Recently, parallel to increase interest to wild edible fruits by consumers in Turkey, the number of scientific studies are also increased on it. However, studies on oleaster-leafed pear (Pyrus elaeagrifolia) are limited. In fact, the plant is well known for centuries by local peoples. The natural growing areas of this unique plant is covered by dry and calcareous areas in particular central and eastern Anatolia and the plant faced environment stress conditions. But the plant naturally resistant against severe climate conditions including cold, heat, calcareous soils etc. (Yilmaz et al., 2015; Gercekcioglu et al., 2016).

Morphologically plant height of oleaster-leafed pear starts from 3-4 m as shrub and reach maximum 10-11 m as small tree. Grey-green hairy leaves of the plant are quite attractive and young shoots are grey and highly hairy and branches are in general thorny (Sagbas et al., 2021). The plant bears pseudocarp fruits in 30-40 mm in diameter and fruits has in general spherical-pear shape. As a member of Pyrus genus, its fruits sandy and include stone cells. There were differences among seed propagated oleaster-leafed pear in terms of stone cell formation (Gercekcioglu et al., 2016).

Oleaster-leafed pear fruits maturate very late between October and December and along with fresh consumption, in particular rural peoples process it into several products such as molasses, jam, pickle, vinegar or syrup due to its better organoleptic properties and fruits are also used as tea (Cansaran et al., 2007).

In Turkey and the other Oleaster-leafed pear grown countries such as Albania, Bulgaria, Greece, Romania, Crimea and Caucasus countries its seedlings are used as rootstocks for commercial pear cultivars for a long time (Yerliturk et al., 2008; Bozhuyuk and Aslantas, 2020). Turkey has rich population of this plant and Oleaster-leafed pear is distributed mainly inner and eastern Anatolia that has typical steppe climate. In particular Erzurum, Erzincan, Kars, Ardahan and Artvin provinces located in eastern Anatolia have dense population of Oleaster-leafed pear even in some areas its dense shrubs and small trees forms a small forest community. It is interesting that within same small populations including 100-200 Oleaster-leafed pear shrubs/small trees shows great morphological and phenological diversity in terms of plant growth habit, fruit mass, maturation period, leaf characteristics etc. (Sagbas et al., 2021).

In this study it is aimed to determine some important phenological and morphological traits of eight naturally grown seed propagated Oleaster-leafed pear ecotypes grown in Sarikamis district located in eastern Anatolia region in Turkey.

\section{MATERIAL AND METHOD}

A total of eight wild grown Oleaster-leafed pear plants naturally propagated by seeds and grown in rural areas of Sarikamis district of Kars province in eastern Turkey were used. The pre-selected genotypes (shows better horticultural characteristics in natural growing conditions such as high yield, free of pest and diseases, attractive fruits) were harvested in 2019 year. Plant architecture (shrub, small tree, tree), growth habit (upright, semi upright, spreading), plant vigor (weak, medium, strong), lenticels on one-year-old shoot (few, medium, many), anthocyanin coloration of growing tip on young shoot (absent, medium, strong), fruit ground color (yellow, green, yellowgreen), fruit mass $(\mathrm{g})$, fruit shape index, fruit pedicle length $(\mathrm{mm})$, fruit firmness $\left(\mathrm{kg} \mathrm{cm}^{-2}\right)$, fruit flesh texture and fruit juiciness (low, medium, high) were determined. Fruit mass (g) was determined on 30 fruits with a digital scale sensitive to $0.01 \mathrm{~g}$. Fruit firmness was determined with hand penetrometer $\left(\mathrm{kg} \mathrm{cm}^{-2}\right)$. The shape was determined as fruit length/width. A panel of five experts evaluated the fruit flesh texture and noted as highly sandy, sandy and slightly sandy for each genotype.

\section{Statistical Analysis}

All data were analyzed using SPSS software and procedures. Analysis of variance tables were constructed using the Least Significant Difference (LSD) method at $\mathrm{P}<0.05$. 


\section{RESULTS AND DISCUSSION}

\section{Phenological and Morphological Characterization}

In this study it is attempted to describe phenological (including ripening period) and morphological parameters including plant growth habit, plant vigor, lenticels on one-year-old shoot, anthocyanin coloration of growing tip on young shoot, fruit ground color, fruit mass, fruit shape index, fruit pedicel length, fruit flesh texture, fruit firmness, and fruit juiciness of eight pre-selected promising oleaster-leafed pear (Pyrus elaeagrifolia) ecotypes.

The ecotypes showed ripening period from 25 October (S8) to 21 November (S6) (Table 1) indicating 27 days intervals between the earliest and the latest ripened ecotypes. Karatas and Ercisli (2021) reported ripening dates of oleaster-leafed pear ecotypes were between 18 October and 07 November in eastern Turkey. Sagbas et al. (2021) found harvest dates of oleaster-leafed pear were between 24 October and 10 November. Yilmaz et al. (2015) used a number of Pyrus elaeagrifolia Pall. subsp. elaeagrifolia genotypes in middle Anatolia and observed a great phenological differences on genotypes for harvest date which ranged from 11 October to 10 November. Our phenological data on harvest time are very close to above studies. Among ecotypes, 3 ecotypes have semiupright, 2 genotypes had spreading and 3 ecotypes had upright growth habit (Table 1 ) indicating relatively enough diversity on this character. Plant vigor was also variable and 4 genotypes had medium, and 4 genotypes had strong vigor traits. In terms of plant architecture 4 ecotypes had shrub, 3 ecotypes had small tree and one ecotype had tree plant architecture. Lenticels on one-year-old-shoot and anthocyanin coloration of growing tip on young shoot were also variable among ecotypes (Table 1). The ecotypes S1, S4, S7 had few lenticels on shoot while 66 had many. Anthocyanin coloration on young shoot were medium in 4 ecotypes and strong in 3 ecotypes. Only one ecotype, S3 absent anthocyanin coloration on young shoots (Table 1). Previously no published papers related to lenticels on one-year-old-shoot and anthocyanin coloration of growing tip on young shoot in Oleasterleafed pear were found. This highlighted the importance of this study.

Table 1. Phenological and morphological characteristics of Pyrus elaeagrifolia genotypes. Çizelge 1. Pyrus elaeagrifolia genotiplerinin fenolojik ve morfolojik özellikleri.

\begin{tabular}{lllllll}
\hline Genotypes & $\begin{array}{l}\text { Ripening } \\
\text { date }\end{array}$ & $\begin{array}{l}\text { Growth } \\
\text { habit }\end{array}$ & $\begin{array}{l}\text { Plant } \\
\text { vigor }\end{array}$ & $\begin{array}{l}\text { Plant } \\
\text { architecture }\end{array}$ & $\begin{array}{l}\text { Lenticels on one- } \\
\text { year-old-shoot }\end{array}$ & $\begin{array}{l}\text { Anthocyanin coloration of } \\
\text { growing tip on young shoot }\end{array}$ \\
\hline S1 & 16 Nov. & Semi-upright & Medium & Shrub & Few & Medium \\
S2 & 28 Oct. & Spreading & Strong & Shrub & Medium & Strong \\
S3 & 26 Oct. & Spreading & Strong & Shrub & Medium & Absent \\
S4 & 13 Nov. & Semi-upright & Medium & Shrub & Few & Medium \\
S5 & 30 Oct. & Semi-upright & Medium & Small tree & Medium & Medium \\
S6 & 21 Nov. & Upright & Strong & Small tree & Many & Strong \\
S7 & 04 Nov. & Upright & Medium & Small tree & Few & Medium \\
S8 & 25 Oct. & Upright & Strong & Tree & Medium & Strong \\
\hline
\end{tabular}

Fruit mass were in range of 8.36 to $16.11 \mathrm{~g}$ indicates a 2 -fold difference between the ecotypes with the lowest fruit mass and the ecotype with the highest fruit mass (Table 2). Shape index were changed from 0.87 to 1.07 . Fruit pedicel length and fruit firmness were found between 9.13 to $16.32 \mathrm{~mm}$ and 4.47 to $7.89 \mathrm{~kg} \mathrm{~cm}^{-2}$, respectively. The majority of ecotypes had green ground fruit color but there were ecotypes that has yellow and yellow-green ground color in its fruits (Table 2). Karatas and Ercisli (2021) reported fruit mass, shape index, pedicel length and fruit firmness in the range of $6.19 \mathrm{~g}$ to $21.04 \mathrm{~g} ; 0.75$ to $1.03 ; 7.11 \mathrm{~mm}$ to $18.56 \mathrm{~mm}$ and 3.84 to $8.22 \mathrm{~kg} \mathrm{~cm}^{-2}$, respectively in Oleaster-leafed pear ecotypes in Turkey. Sagbas et al. (2021) indicated that among Oleaster-leafed pear ecotypes, some had bigger fruits around $19 \mathrm{~g}$ and some genotypes had lower fruit mass as $5.73 \mathrm{~g}$. Similar high variations on fruit mass were obtained in Pyrus elaeagrifolia Pall. subsp. elaeagrifolia genotypes by Yilmaz et al. (2015) as 4.71-27.09 g and Gercekcioglu et al. (2016) as 16-22 g, respectively. Kececi et al. (2017) also reported higher fruit mass variation between 18.05-55.50 g among Pyrus elaeagrifolia Pall. subsp. elaeagrifolia genotypes sampled from Hakkari region in eastern Turkey. Gercekcioglu et al. (2016) reported a great variation on the fruit firmness between 4-8 and 4-10 kg cm${ }^{-2}$ among Oleaster-leafed pear. In terms of fruit flesh texture, 4 genotypes had slightly sandy, 3 ecotypes had sandy and one ecotype had highly sandy fruit traits (Table 2). Half of the ecotypes had medium and half of the ecotypes had low fruit juiciness (Table 2). Karatas and Ercisli (2021) reported that fruit flesh texture varied from highly sandy (8 genotypes), sandy (12 genotypes) to slightly sandy (6 genotypes), respectively. Yilmaz et al. (2015) and reported that among 43 Pyrus elaeagrifolia genotypes, 20 
genotypes had sandy fruit, 12 genotypes had highly sandy and 11 genotypes had slightly sandy fruits which in accordance with our results.

Table 2. Phenological and morphological characteristics of Pyrus elaeagrifolia genotypes.

Çizelge 2. Pyrus elaeagrifolia genotiplerinin fenolojik ve morfolojik özellikleri.

\begin{tabular}{|c|c|c|c|c|c|c|}
\hline Genotypes & $\begin{array}{l}\text { Pedicel } \\
\text { length (mm) }\end{array}$ & $\begin{array}{l}\text { Fruit ground } \\
\text { color }\end{array}$ & Fruit mass (g) & Fruit shape index & $\begin{array}{l}\text { Fruit firmness } \\
\left(\mathrm{kg} \mathrm{cm}^{-2}\right)\end{array}$ & $\begin{array}{l}\text { Fruit flesh } \\
\text { texture }\end{array}$ \\
\hline S1 & 15.22ab* & Yellow-Green & $14.42 b$ & $1.00 c$ & $6.68 b c$ & Slightly sandy \\
\hline S2 & $16.32 a$ & Green & 9.14de & $0.93 c d$ & $4.47 d$ & Slightly \\
\hline S3 & 14.10ab & Yellow-Green & $9.67 d$ & $1.07 a$ & $5.11 \mathrm{c}$ & Sandy \\
\hline S4 & $9.13 c$ & Green & $16.11 a$ & $1.04 \mathrm{~b}$ & 7.02ab & Slightly Sandy \\
\hline S5 & $11.40 \mathrm{~b}$ & Green & 8.36de & $1.04 \mathrm{~b}$ & $5.36 \mathrm{bc}$ & Sandy \\
\hline S6 & 10.98ab & Yellow & $11.37 c$ & $0.99 \mathrm{~cd}$ & 7.11ab & Slightly Sandy \\
\hline S7 & $10.74 a b$ & Green & $10.42 \mathrm{~cd}$ & $0.87 d$ & $6.95 b$ & Highly Sandy \\
\hline S8 & $9.77 \mathrm{bc}$ & Green & 9.93cde & $0.93 \mathrm{~cd}$ & $7.89 a$ & Sandy \\
\hline
\end{tabular}

*Same letters in same column indicate statistically significant differences $(P<0.05)$ among the genotypes

\section{CONCLUSION}

As a conclusion, the study revealed the morphological diversity of some oleaster-leafed pear ecotypes that are wild grown in Sarikamis district of Kars province in the Eastern Anatolia region. As a result of increasing globalization in the world, unplanned selection and breeding studies and intensive agricultural practices, there has been a significant decrease in the number of fruit varieties. The widespread cultivation of standard varieties of foreign origin with modern methods has led to the extinction of local varieties, which can be of great importance especially in breeding studies. Preventing this situation depends on the determination of gene sources and their protection.The genotypes S1, S4 and S6 can be advanced for commercial cultivation; furthermore, other genotypes can be used as source of breeding lines for genetic improvement of oleaster-leafed pears.

\section{CONFLICT OF INTEREST}

The author have declared no conflict of interest.

\section{DECLARATION OF AUTHOR CONTRIBUTION}

As an author, the planning, preparation, analysis of experiment and writing of the manuscript was done by me.

\section{REFERENCES}

Bozhuyuk, M. R., \& Aslantas, R. (2020). Molecular characterization of Turkey's Coruh Valley pears by SSR. Acta Horticulturae, 1297, 367-376.

Cansaran, A., Kaya, O. F., \& Yildirim, C. (2007). An ethnobotany study on Ovabasi, Akpinar, Gulluce and Koseler villages (Gumushacikoy/Amasya). Firat University Science and Engineering Journal, 19, 243-257.

Ercisli, S., \& Sagbas, H. I. (2017). Wild Edible Fruits: A Rich Source of Biodiversity. Anadolu, 27(2), 116-122.

Gercekcioglu, R., Ozluk, A., \& Atasever, O. (2016). Selection of Pyrus elaeagnifolia L. from Merzifon district. Bahce, 2, 69-73.

Karatas, N., \& Ercisli, S. (2021). Fruit characteristics of Pyrus elaeagrifolia Pall. genotypes in Eastern Turkey. Proceedings of X International Symposium on Agricultural Sciences, 24-32.

Kececi, L. D. (2017). Determination of some horticultural characteristics of Pyrus elaeagrifolia L. genotypes from Hakkari region. (Master of Science, Adnan Menderes University, Graduate School of Natural and Applied Sciences, Aydin, Turkey.

Sagbas, H. I., Ilhan, G., Ercisli, S., Anjum, M. A., \& Holubec, V. (2021). Characterization of Oleaster-Leafed Pear (Pyrus elaeagrifolia Pall. subsp. elaeagrifolia) fruits in Turkey. Agronomy, 11, 430. 
Sezen, I., Ercisli, S., Cakir, O., Koc, A., Temim, E., \& Hadziabulic, A. (2015). Biodiversity and Landscape Use of Sea Buckthorn (Hippophae rhamnoides L.) in the Coruh Valley of Turkey. Erwerbs-Obstbau, 57, 23-28.

Tetik, N., Turhan, I., Oziyci, H. R., Gubbuk, H., Karhan, M., \& Ercisli, S. (2011). Physical and chemical characterization of Ceratonia siliqua L. germplasm in Turkey. Scientia Horticulturae, 129, 583-589.

Yerliturk F. U., Arslan, O., Sinan, S., Gencer, N., \& Ozensoy, O. G. (2008). Characterization of polyphenol oxidase from wild pear (Pyrus elaegnifolia). Journal of Food Biochemistry, 32, 368-383.

Yildiz, H., Sengul, M., Celik, F., Hegedus, A., Ercisli, S., \& Tosun, M. (2010). Some phytochemical and antioxidant characteristics of wild and cultivated blackberry (Rubus caucasicus) fruits. Journal Food Agriculture and Environment, 8 (3-4), 156-159.

Yilmaz, K. U., Uzun, A., Cam, M., \& Ercisli, S. (2015). Some morphological and fruit characteristics of naturally grown Pyrus elaeagnifolia Pall. of Kayseri province (Central Anatolia, Turkey). Genetic Resources and Crop Evolution, 62, 711-720. 